\title{
The Effect of Gonadotropin Releasing Hormone Administration on Fertility and Embryonic Loss in Goats during the Anoestrus Period
}

\author{
Ayşe Merve Köse' ${ }^{1}$ Ece Koldaş Ürer ${ }^{1}$, Mustafa Kemal Sarıbay', Gökhan Doğruer' \\ Fikret Karaca ${ }^{2}$, Nurdan Çoskun Çetin² \& Haydar Demirezer ${ }^{2}$
}

\begin{abstract}
Background: Following the induction of oestrus out of season in small ruminants, low fertility and variations in fertility rates are associated with embryonic losses. One of the main causes of embryonic loss is luteal dysfunction. Gonadotropin Releasing Hormone $(\mathrm{GnRH})$ supports the luteal structure, and increasing progesterone levels may be beneficial in terms of promoting embryonic life. The main objective of the present study was to evaluate the efficacy of GnRH administration following an oestrus induction protocol in the anoestrus season for preventing embryonic loss in goats having failure to conceive during the season.

Materials, Methods \& Results: In the study, 106 Damascus goats aged 3-5 years and weighing 45-60 kg were used. The oestrus of 106 goats in the anoestrous group was stimulated with progesterone and pregnant mare serum gonadotropin (PMSG) treatment. Out of breeding season, goats were divided into the 4 following groups: $\mathrm{GnRH}_{0}(\mathrm{n}=27), \mathrm{GnRH}_{7}(\mathrm{n}=$ 26), $\mathrm{GnRH}_{0+7}(\mathrm{n}=27)$ and control $(\mathrm{n}=26)$. In each goat, an intravaginal sponge (IS) containing $20 \mathrm{mg}$ of fluorogestone acetate (FGA) was placed into the vagina and left for 9 days. With the withdrawal of the sponge, 550IU PMSG and 125 $\mu \mathrm{g}$ of d-cloprostenol were injected intramuscularly. Oestrus detection was made via teaser bucks for 3 days starting $24 \mathrm{~h}$ after withdrawal of the IS. Eighteen bucks known to be fertile were used for breeding. Goats in the oestrus period were mated via natural breeding. The GnRH analogue lecirelin was injected intramuscularly at breeding in the $\mathrm{GnRH}_{0}$ group, on day 7 post-breeding in the $\mathrm{GnRH}_{7}$ group, and both at breeding and on day 7 post-breeding in the $\mathrm{GnRH}_{0+7}$ group. No injections were given to the control group. Blood samples for progesterone measurement were taken by jugular vena puncturing on days $3,6,7,10,13,16$, and 19 after breeding from 10 randomly chosen goats in all groups. The goats with a level of $>3.5 \mathrm{ng} / \mathrm{mL}$ of progesterone on day 21 post-breeding were evaluated as pregnant. Pregnancy was also viewed on day 50 after breeding by real-time ultrasonography (USG) with a 5-7.5 MHz convex probe. The oestrus rate was $96.23 \%$ $(102 / 106)$ in the goats. The rates of onset of oestrus between $36-48 \mathrm{~h}, 48-60 \mathrm{~h}$ and $60 \mathrm{~h}$ and beyond were $38.7 \%(41 / 106)$, $21.7 \%$ (23/106) and 35.8\% (38/106), respectively. The total pregnancy rate was $35.8 \%$ (38/106). There were no statistically significant differences $(P>0.05)$ found for the pregnancy rate, embryonic death rate or progesterone concentration of the groups. However, serum progesterone levels were statistically different in the $\mathrm{GnRH}_{7}$ group compared with the control group $(P<0.05)$.

Discussion: After synchronisation, various anti-luteolytic strategies can be used to support corpus luteum development and elevate progesterone concentration in the luteal phase to decrease embryonic loss and increase reproductive performance. Therefore, application of GnRH to support the luteal structure and to increase progesterone levels may be beneficial in terms of supporting embryonic life. The results showed that GnRH treatment on the day 7 post-breeding following oestrus induction, including FGA and PMSG, can increase serum progesterone levels in Damascus goats in the anoestrus period. However, following oestrus induction in the anoestrus period, it was seen that GnRH treatment at breeding or on day 7 after breeding did not have any positive effect on embryonic loss or reproductive performance. In conclusion, it was considered that this protocol could be implemented successfully, yielding a 35\% pregnancy rate in Damascus goats in the anoestrus period, but embryonic loss must be deeply studied in detail.
\end{abstract}

Keywords: anoestrus, embryonic loss, oestrous induction, GnRH, goat. 


\section{INTRODUCTION}

From goats that fail to conceive during the breeding season, pregnancy can be achieved with applications performed outside the breeding season $[9,15]$; for instance, gonadotropin combined with progestogens is widely used for the induction of oestrus [20,32]. It has been reported that the fertility rate in the anoestrus period varies between $33 \%$ and $77 \%$ after these applications [10]. Following the induction of oestrus outside the breeding season, low fertility and variations in the fertility rate between studies are caused by embryonic loss [10,14]. The main reasons for embryonic loss are luteal function deficiency, embryo-uterine asynchronisation and insufficient embryo development [16].

Different therapeutic strategies have been implemented to reduce embryonic loss and increase fertility performance after synchronisation protocols. Binelli et al. [6] classified anti-luteolytic strategies into 6 categories, one of which is to increase the luteal progesterone level. Here, luteotrophic hormones, such as $\mathrm{GnRH}$ or human chorionic gonadotropin (hCG), are used in the early luteal phase or the late luteal phase. Administering these hormones in the luteal phase provides accessory corpus luteum formation by acting directly or indirectly in the ovaries, resulting in an increased serum progesterone concentration $[8,16]$. In many ruminants, the administration of GnRH during mating or prior to maternal recognition is considered to support embryo viability by improving luteal function, inducing the luteinisation of developing follicles, and increasing the blood progesterone level [21,24]. This study aimed to determine the effect of GnRH administration following an oestrus induction protocol on fertility and embryonic loss in goats.

\section{MATERIALS AND METHODS}

\section{Animals}

This study was carried out on a commercial goat farm (Pan Hayvancılık, Nurdağı/Gaziantep) located at a latitude of $36^{\circ} 90^{\prime} \mathrm{N}$ and a longitude of $37^{\circ} 15^{\prime} \mathrm{E}$. In this study, 106 Damascus goats aged 3-5 years and weighing 45-60 kg were used. All goats had been mated in the preceding breeding season, but they did not become pregnant. The daily milk average of the goats was $1.75 \mathrm{~L}$. The goats were fed by ration with $2,800 \mathrm{kcal} / \mathrm{kg} \mathrm{ME}$ and $18 \%$ crude protein. Water was given ad libitum.
Oestrus induction and study design

Out of breeding season, oestrus was stimulated with an intravaginal sponge (IS) containing $20 \mathrm{mg}$ of fluorogestone acetate ${ }^{1}, \mathrm{PMSG}^{2}$ and d-cloprostenol ${ }^{3}$. The IS was placed into the vagina and left for 9 days. With the withdrawal of the IS, 550IU PMSG2 and 125 $\mu \mathrm{g}$ of d-cloprostenol ${ }^{3}$ were injected intramuscularly. Oestrus detection was made by teaser bucks for 3 days, starting $24 \mathrm{~h}$ of withdrawal of the IS. Eighteen bucks known to be fertile were used for breeding. Goats in oestrus were mated by natural breeding within $1 \mathrm{~h}$. The goats were divided into the 4 following groups: $\mathrm{GnRH}_{0}$ $(\mathrm{n}=27), \mathrm{GnRH}_{7}(\mathrm{n}=26), \mathrm{GnRH}_{0+7}(\mathrm{n}=27)$ and control $(\mathrm{n}=26)$. GnRH analogue $25 \mu \mathrm{g}$ lecirelin ${ }^{3}$ was injected intramuscularly at breeding in the GnRHO group, on day 7 post-breeding in GnRH7 group, and both at breeding and on day 7 post-breeding in $\mathrm{GnRH}_{0+7}$. No injection was given in the control group.

\section{Serum samples and progesterone measurements}

Blood samples for progesterone measurement were taken into anticoagulated tubes ${ }^{4}$ by jugular vena puncturing on days $3,6,7,10,13,16$ and 19 days after breeding from 10 randomly chosen goats in all groups. Blood sampling was also performed for all goats on day 21. Blood samples were centrifuged ${ }^{5}$ for $10 \mathrm{~min}$ at $2000 \mathrm{~g}$. Separated serum samples were kept in a freezer at $-20{ }^{\circ} \mathrm{C}$ until analysis. Serum progesterone levels were analysed using an electrochemiluminescent method in an autoanalyzer ${ }^{6}$.

\section{Pregnancy diagnosis}

Pregnancy diagnosis was carried out both by means of progesterone at 21 days post-breeding and USG 50 days after breeding was performed, as previously described [13]. Goats with a level of $>3.5 \mathrm{ng} / \mathrm{mL}$ progesterone on day 21 post-breeding were evaluated as pregnant. In addition, pregnancy was viewed on day 50 after breeding using real-time $\mathrm{USG}^{7}$ with a 5-7.5 $\mathrm{MHz}$ convex probe.

\section{Formulae for reproductive parameters}

Oestrus rate: (Goats in oestrus/total number of goats) x 100

Onset of oestrus: Interval between withdrawal of sponge and breeding

Pregnancy rate: (Number of pregnant goats/ total number of goats) $\mathrm{x} 100$ 
Parturition rate: (Number of goats delivering/ total Number of goats) x 100

Multiple birth rate: (Number of goats giving multiple birth/number of goats delivering) x 100

Litter size: (Number of kids born/number of goats delivering) x 100

Embryonic loss rate: (Number of pregnant goats determined by 21-day progesterone level) (number of pregnant goats determined by positive USG positive at day 50)/number of pregnant goats in group x 100

\section{Statistical analysis}

The pregnancy rate, parturition rate, multiple pregnancy rate and litter size were compared with the Chi-square test using SPSS version 22 software ${ }^{8}$. Progesterone values of different sampling days were also compared using a one-way analysis of variance (ANOVA) test (SPSS22).

\section{RESULTS}

The oestrus rate was $96.23 \%(102 / 106)$ in the goats. The rates of onset of oestrus at 36-48 h, 48-60 $\mathrm{h}$ and $60 \mathrm{~h}$ and beyond were $38.7 \%$ (41/106), $21.7 \%$ $(23 / 106)$ and $35.8 \%(38 / 106)$, respectively. The total pregnancy rate was $35.8 \%$ (38/106). Fertility parameters of the GnRH0, GnRH7, $\mathrm{GnRH}_{0+7}$ and control groups are given in Table 1. Progesterone values of goats on different days of pregnancy are presented in Table 2.

Table 1. Fertility parameters of $\mathrm{GnRH}_{0}, \mathrm{GnRH}_{7}, \mathrm{GnRH}_{0+7}$ and Control groups.

\begin{tabular}{ccccc}
\hline \multirow{2}{*}{ Parameter } & \multicolumn{3}{c}{ Groups } \\
\cline { 2 - 5 } ConRH & $\mathrm{GnRH}_{7}$ & $\mathrm{GnRH}_{0+7}$ & $88.5(23 / 26)$ \\
\hline Pregnancy rate* $(\%)$ & $70.4(19 / 27)$ & $88.5(23 / 26)$ & $70.4(19 / 27)$ & $46.2(12 / 26)$ \\
Pregnancy rate** (\%) & $33.3(9 / 27)$ & $38.5(10 / 26)$ & $25.9(7 / 27)$ & $47.8(11 / 23)$ \\
Embryonic loss rate (\%) & $52.6(10 / 19)$ & $56.5(13 / 23)$ & $63.1(12 / 19)$ & $83.3(10 / 12)$ \\
Parturition rate (\%) & $77.8(7 / 9)$ & $100(10 / 10)$ & $100(7 / 7)$ & $50(6 / 12)$ \\
Multiple birth rate (\%) & $44.4(4 / 9)$ & $30(3 / 10)$ & $28.6(2 / 7)$ & $1.28(9 / 7)$ \\
Litter size (x/n) & $1.57(11 / 7)$ & $1.5(15 / 10)$ & $19 / 10)$ \\
\hline
\end{tabular}

*According to 21st day progesteron level; **According to USG examination on 50th day. Differences between groups were not statistically important. $(P>0.05)$.

Table 2. Progesterone values of goats on different days of pregnancy (ng/mL).

\begin{tabular}{|c|c|c|c|c|}
\hline \multirow{2}{*}{ Day of pregnancy } & \multicolumn{4}{|c|}{ Groups } \\
\hline & $\mathrm{GnRH}_{0}$ & $\mathrm{GnRH}_{7}$ & $\mathrm{GnRH}_{0+7}$ & Control \\
\hline 3 & $6.65 \pm 1.40$ & $4.56 \pm 0.74^{\mathrm{c}}$ & $5.59 \pm 0.95$ & $7.93 \pm 1.97^{b}$ \\
\hline 6 & $6.15 \pm 1.21$ & $6.50 \pm 1.31^{\mathrm{bc}}$ & $9.57 \pm 0.61$ & $5.97 \pm 1.33^{b}$ \\
\hline 7 & $6.55 \pm 1.06$ & $10.66 \pm 1.30^{\mathrm{abc}}$ & $8.11 \pm 2.36$ & $6.67 \pm 1.02^{\mathrm{b}}$ \\
\hline 10 & $5.53 \pm 0.96$ & $8.96 \pm 1.73^{\mathrm{abc}}$ & $7.64 \pm 1.64$ & $7.81 \pm 1.53^{\mathrm{b}}$ \\
\hline 13 & $8.05 \pm 2.82$ & $14.01 \pm 3.24^{\mathrm{a}}$ & $10.71 \pm 1.24$ & $7.40 \pm 1.67^{b}$ \\
\hline 16 & $5.70 \pm 1.06$ & $12.85 \pm 3.02^{\mathrm{ab}}$ & $8.11 \pm 2.11$ & $5.74 \pm 1.55^{\mathrm{b}}$ \\
\hline 19 & $7.71 \pm 2.84$ & $8.04 \pm 1.49^{\mathrm{abc}}$ & $8.06 \pm 3.30$ & $16.39 \pm 3.65^{\mathrm{a}}$ \\
\hline 21 & $6.97 \pm 1.65$ & $11.39 \pm 2.32^{\mathrm{ab}}$ & $5.06 \pm 1.89$ & $7.39 \pm 1.52^{b}$ \\
\hline
\end{tabular}

Values with different letter on the same column were statistically important $(P<0.05)$.

\section{DISCUSSION}

In this study, it was aimed to impregnate goats that had not been pregnant during the breeding season using an oestrus stimulation protocol to reveal the effect of GnRH injection at breeding and after breeding on reproductive performance and embryonic loss. After synchronisation, various anti-luteolytic strategies can be used to support corpus luteum development and elevate progesterone concentration in the luteal phase to decrease embryonic loss and increase reproductive 
performance [6]. Therefore, application of GnRH to support the luteal structure and increase progesterone levels may be beneficial in terms of supporting embryonic life [11].

Previous research has found that, in the anoestrus period, pregnancy rates of goats exposed to different durations of vaginal sponge for inducing oestrus vary in the range of $33-77 \%[1,5,19,29]$. In this study, the pregnancy rates of the GnRH0, GnRH7, $\mathrm{GnRH}_{0+7}$ and control groups were $33.3 \%, 38.5 \%, 25.9 \%$ and $46.2 \%$, respectively $(P>0.05$; Table 1$)$. Akar et al. [2] reported that, after a short-term synchronisation protocol including intravaginal progesterone (for 7 days) and 500IU PMSG plus $75 \mu \mathrm{g}$ of d-cloprostenol, the oestrus rate was $88.7 \%$; furthermore, the pregnancy rate was $28.89 \%$ in the GnRH treatment group, in which GnRH injection was administered 12 days after breeding, whereas it was $37.21 \%$ in the control group with no GnRH treatment implemented. According to Sarıbay et al. [31], in the anoestrus period, after a long oestrus synchronisation protocol (14 days) involving progesterone, PMSG and cloprostenol, the oestrus rate was $100 \%$; moreover, the pregnancy rate was $38.1 \%$ in the $\mathrm{GnRH}$ treatment group in which a single-dose GnRH injection was administered $48 \mathrm{~h}$ after withdrawal of the sponge, and in the control group, the pregnancy rate was $33.3 \%$. Fonseca and Torres [18] reported that, following the oestrus synchronisation protocol involving intravaginal progesterone treatment for 9 days and 220IU PMSG plus d-cloprostenol, the oestrus rate was $83.1 \%$, and the pregnancy rate of the hCG treatment group injected with hCG on day 5 after breeding was $50 \%$; the pregnancy rate was $68 \%$ in the control group. In the present study, in goats having failure to conceive during the season in the breeding season, with the oestrus induction protocol including progesterone and 550IU PMSG plus $125 \mu \mathrm{g}$ of d-cloprostenol, the oestrus rate was $96.23 \%$ in the treatment groups, whereas the pregnancy rate was $46.2 \%$ in the control group (Table 1). These results were observed to be similar to those of previous studies. In addition, the oestrus induction protocol used in goats with failure to conceive during the season can be considered successful.

Whereas oestrus induction was successful, GnRH application at different times after breeding did not improve the pregnancy rate. No statistical difference could be identified between the treatment groups in terms of fertility parameters (pregnancy rate, multiple pregnancy rate, and litter size). GnRH agonists can affect the pituitary gland (PG) in different ways because of their dissimilar chemical structures. In addition, single GnRH injection can result in high gonadotropin release and an increased number of receptors (fivefold for follicle stimulating hormone [FSH] receptors and tenfold for luteinising hormone $[\mathrm{LH}]$ receptors). However, continuous treatment with GnRH agonists may also cause adverse effects by impairing $\mathrm{LH}$ release, leading to insensitisation of the PG to GnRH or decreasing the response of PG to GnRH [30]. In one study, higher levels of plasma progesterone concentration were detected in the treatment group (PMSG 500IU) compared with the control group [27]. It has also been reported that, because of the luteotrophic effect of PMSG used in oestrus induction protocols, the effects of GnRH and hCG can be masked by PMSG treatment [18]. In the present study, it was thought that the reason for the high fertility level in the control group may be due to the mentioned effects of GnRH.

In the out-of-season period, the onset of oestrus was 15.4-44.6 $\mathrm{h}$ after the withdrawal of IS. This variation resulted from different breeds, geographic locations and durations of IS treatment [12,17,23,25,33,34]. In this study, after withdrawal of the IS, the rate of oestrus onset at $36-48 \mathrm{~h}$ was $38.7 \%$ (41/106), that at 48 $60 \mathrm{~h}$ was $21.7 \%(23 / 106)$, and that at $60 \mathrm{~h}$ and beyond was $35.8 \%$ (38/106). While the onset of oestrus in this study was similar to the results of some previous studies $[17,33,34]$, in other research, the onset of oestrus was earlier than in the present findings [12,22,23,25]. It can be said that these differences may be caused by synchronisation procedures, hormone and breed differences. Alaçam et al. [3] stated that GnRH injection on day 12 post-breeding can improve fertility in Angora goats. Cam and Kuran [7] indicated that GnRH injections on day 12 post-breeding can improve breeding performance. In the same way, Uslu and Gülyüz [33] stated that $\mathrm{GnRH}$ injection after breeding has a positive effect on the pregnancy rate. In contrast, some studies have shown that hCG and GnRH injection after breeding are not beneficial for increasing fertility or the pregnancy rate $[2,4,26,31]$. This study does not support the hypothesis that GnRH treatment at breeding and after breeding prevents embryonic loss and improves reproductive performance. One study showed that the differences between previous research resulted 
from different physiological statuses brought about by the different study designs, nutritional statuses, farm conditions and oestrus induction protocols in different works [16]. In addition, breed, time of treatment or dosage of drugs can have a critical effect on pregnancy rate and embryo viability. In the present study, the embryonic loss rates were $52.6 \%, 56.5 \%, 63.1 \%$ and $47.8 \%$ in the GnRH0, GnRH7, GnRH0+7 and control groups, respectively. No statistical difference could be found $(P>0.05$; Table 1).

Some studies have reported that post-insemination $\mathrm{GnRH}$ treatment can be successful in preventing embryonic loss in sheep [8,16,21]. In this study, GnRH addition to the oestrus induction protocol was not effective in reducing embryonic death in goats. When the oestrus synchronisation protocol was implemented in the out-of-season period, embryonic loss was higher than that in the breeding period. Many processes, such as ovulation, fertilisation, corpus luteum lifespan and implantation, are the main reasons for embryonic loss underlaid by. In the same way, the formation and lifespan of the corpus luteum in the breeding period have been found to be longer than that in the non-breeding period [28]. In one study, the plasma progesterone concentration after hCG treatment applied on the fifth day after breeding increased between day 7 (4.7 \pm 1.9 and $3.9 \pm 1.8 \mathrm{ng} / \mathrm{mL})$ and day $13(8.1 \pm 3.2$ and $5.2 \pm$ $2.0 \mathrm{ng} / \mathrm{mL}$ ) by up to $33 \%$ and $72 \%$ [18]. However, in the present study, progesterone concentration did not differ statistically on days $3,6,7,10,13,16$ and 19 $(P>0.05$; Table 2).

When the groups were assessed in terms of progesterone concentration, no statistical difference was found in comparing the $\mathrm{GnRHO}$ and $\mathrm{GnRH}_{0+7}$ groups $(P>0.05$; Table 2$)$. However, the serum progesterone level was statistically different in the GnRH7 group compared with the control group $(P<0.05$; Table 2$)$.
In the $\mathrm{GnRH}_{7}$ group, a peak level of progesterone was observed on day 13. This result was similar to that of a previous study [18].

\section{CONCLUSION}

Based on the present study's results, it was observed that GnRH treatment on day 7 post-breeding following oestrus induction including FGA and PMSG can increase serum progesterone levels in Damascus goats in the anoestrus period. However, following the oestrus induction in the anoestrus period, it was seen that GnRH treatment at breeding or on day 7 after breeding did not have any positive effect on embryonic loss and reproductive performance. The oestrus induction protocol can be implemented successfully, yielding a $35 \%$ pregnancy rate in Damascus goats in the anoestrus period, but embryonic loss must be deeply studied in detail.

\section{MANUFACTURERS}

${ }^{1}$ MSD Santé Animale. Igoville, France.

${ }^{2}$ Intervet, International B.V. Boxmeer, Netherlands.

${ }^{3}$ Vetaş, DEVA Holding A.Ş. Tekirdağ, Turkey.

${ }^{4}$ Becton, Dickinson and Company. Franklin Lakes, NJ, USA.

${ }^{5}$ Nüve Sanayi Malz, İma ve Ticaret A.Ş. Ankara, Turkey.

${ }^{6}$ Siemens Healthcare GmbH. Erlangen, Germany.

${ }^{7}$ Pie Medical Imaging. Maastricht, Netherlands.

${ }^{8}$ International Business Machines Corporation. Armonk, NY, USA.

Funding. This study was supported by the Hatay Mustafa Kemal University Scientific Research Project Coordination Unit with project number 15126 .

Ethical approval. This study was conducted pursuant to approval of the Ethics Board of Hatay Mustafa Kemal University, Animal Experiments Local Ethics Committee (no. 2015/9-4).

Declaration of interest. The authors report no conflicts of interest. The authors alone are responsible for the content and writing of the paper.

\section{REFERENCES}

1 Ahmed M.M., Makawi S.E. \& Jubara A.S. 1998. Synchronization of oestrus in Nubian goats. Small Ruminant Research. 30(2): 113-120.

2 Akar Y., Yüksel M. \& Ograk Y.Z. 2014. Oestrus synchronization and reproductive performance under different protocols in anoestrus dairy goats. Research Opinions in Animal \& Veterinary Sciences. 4(8): 432-436.

3 Alaçam E., Güven S., Ayar A. \& Saban E. 1999. Effect of gonadoreline administration on blood progesterone, oestradiol $17 \beta$ concentration and some fertility parameters in Angora goats. Turkish Journal of Veterinary and Animal Sciences. 23(1): 77-81.

4 Baki Acar D., Birdane M.K., Özenç E., Yeni D. \& Doğan İ. 2013. Effectiveness of different progesterone analogues and GnRH on reproductive parameters in nulliparous Saanen goats at the end of the transition period. Kafkas Üniversitesi Veteriner Fakültesi Dergisi. 19(A): 181-186. 
5 Baril G., Remy B., Vallet J.C. \& Beckers J.F. 1992. Effect of repeated use of progestagen PMSG treatment for estrus control in dairy goats out of breeding season. Reproduction in Domestic Animals. 27(3): 161-168.

6 Binelli M., Thatcher W.W., Mattos R. \& Baruselli P.S. 2001. Antiluteolytic strategies to improve fertility in cattle. Theriogenology. 56(9): 1451-1463.

7 Cam M.A. \& Kuran M. 2004. Effects of a single injection of hCG or GnRH agonist on day 12 post mating on fetal growth and reproductive performance of sheep. Animal Reproduction Science. 80(1): 81-90.

8 Cam M.A., Kuran M., Yildiz S. \& Selcuk E. 2002. Fetal growth and reproductive performance in ewes administered GnRH agonist on day 12 post-mating. Animal Reproduction Science. 72(1): 73-82.

9 Cengiz M. \& Çolak A. 2017. Reproduction management in sheep and goats in anoestrus period. Turkiye Klinikleri Veterinary Sciences Obstetrics and Gynecology Special Topics. 3(2): 99-106.

10 Chao L.M., Takayama K., Nakanishi Y., Hamana K., Takagi M., Kubota C. \& Kojima T. 2008. Luteal lifespan and fertility after estrus synchronization in goats. Journal of Veterinary Science. 9(1): 95-101.

11 Cinar M., Ceyhan A., Yilmaz O. \& Erdem H. 2017. Effect of estrus synchronization protocols including PGF2 $\alpha$ and GnRH on fertility parameters in hair goats during breeding season. Journal of Animal and Plant Sciences. 27: 1083-1087.

12 Doğan I., Nur Z., Gunay U., Soylu M.K. \& Sonmez C. 2004. Comparison of fluorgestone and medroxyprogesterone intravaginal sponges for oestrus synchronization in Saanen does during the transition period. South African Journal of Animal Science. 34(1): 18-22.

13 Doğruer G., Karaca F., Koldaş Ürer E., Çoşkun Çetin N., Köse A.M., Ateş C.T., Özcan O. \& Sarıbay M.K. 2019. Determination of efficient CIDR application periods in timed artificial insemination of Damascus goats during the breeding season. Ankara Üniversitesi Veteriner Fakültesi Dergisi. 66: 67-72.

14 Erdem H. \& Sarıbay M.K. 2015. Pregnancy and diagnostic methods. In: Obstetrics and Gynecology in Farm Animals. 2nd edn. Malatya: Medipres, pp.507-521.

15 Fatet A., Pellicer-Rubio M.T. \& Leboeuf B. 2011. Reproductive cycle of goats. Animal Reproduction Science. 124(3): 211-219.

16 Fernandez J., Bruno-Galarraga M.M., Soto A.T., de la Sota R.L., Cueto M.I., Lacau-Mengido I.M. \& Gibbons A.E. 2019. Effect of GnRH or hCG administration on Day 4 post insemination on reproductive performance in Merino sheep of North Patagonia. Theriogenology. 126: 63-67.

17 Fleming S.A., Van Camp S.D. \& Chapin H.M. 1990. Serum progesterone determination as an aid for pregnancy diagnosis in goats bred out of season. Canadian Veterinary Journal. 31(2): 104.

18 Fonseca J.F. \& Torres C.A.A. 2005. Administration of hCG 5 days after breeding and reproductive performance in nulliparous dairy goats. Reproduction Domestic Animal. 40(6): 495-499.

19 Freitas V.J.F., Baril G. \& Saumande J. 1996. Induction and synchronization of estrus in goats: the relative efficiency of one versus two fluorogestone acetate-impregnated vaginal sponges. Theriogenology. 46(7): 1251-1256.

20 González-Álvarez V.H., Meza-Herrera C.A., Leyva C., Alvarado-Espino A.S., Guillén-Muñoz J.M., RodríguezMartínez R. \& Véliz-Deras F.G. 2016. Effectiveness of different hCG and GnRH based protocols in progesterone primed goats on estrus induction and reproductive outcomes in out-off-season goats. Journal of Animal Research. 6: 357.

21 Hashem N.M., El-Azrak K.M., El-Din A.N., Taha T.A. \& Salem M.H. 2015. Effect of GnRH treatment on ovarian activity and reproductive performance of low-prolific Rahmani ewes. Theriogenology. 83(2): 192-198.

22 Kılboz E.İ. \& Karaca F. 2010. Induction of estrus with Flugeston Acetate -Vaginal Sponge and Norgestomet-Ear Implant treatments in young goats in non breeding season. 21(1): 1-6.

23 Leboeuf B., Forgerit Y., Bernelas D., Pougnard J.L., Senty E. \& Driancourt M.A. 2003. Efficacy of two types of vaginal sponges to control onset of oestrus, time of preovulatory LH peak and kidding rate in goats inseminated with variable numbers of spermatozoa. Theriogenology. 60(7): 1371-1378.

24 Luo J., Wang W. \& Sun S. 2019. Research advances in reproduction for dairy goats. Asian-Australasian Journal of Animal Sciences. 32: 1284-1295.

25 Pierson J.T., Baldassarre H., Keefer C.L. \& Downey B.R. 2001. Seasonal variation in preovulatory events associated with synchronization of estrus in dwarf goats. Theriogenology. 56(5): 759-769.

26 Prosperi C.P., Torres C.A.A., Guimarães J.D., Bruschi J.H., Leite P.A.G. \& Maffili V.V. 2006. Pregnancy rate and progesterone concentration of Alpine and Saanen goats treated with hCG the third day after estrus. Arquivo Brasileiro de Medicina Veterinaria e Zootecnia. 58(2): 190-195. 
27 Regueiro M., Clariget R.P., Ganzábal A., Aba M. \& Forsberg M. 1999. Effect of medroxyprogesterone acetate and eCG treatment on the reproductive performance of dairy goats. Small Ruminant Research. 33(3): 223-230.

28 Ritar A.J., Robertson J.A. \& Evans G. 1994. Ovulatory activity, hormonal induction of ovulation and fertility of young Cashmere and Angora female goats in a temperate environment. Reproduction, Fertility and Development. 6(6): 737-747.

29 Robin N., Laforest J.P., Lussier J.G. \& Guilbault L.A. 1994. Induction of estrus with intramuscular injections of GnRH or PMSG in lactating goats (Capra hircus) primed with a progestagen during seasonal anestrus. Theriogenology. 42(1): 107-116.

30 Saleh M. 2011. Synchronization and superovulation of Boer goats with PGF2 and GnRH or hCG and parentage analysis using microsatellite markers. International PhD Program for Agricultural Sciences in Göttingen (IPAG) at the Faculty of Agricultural Sciences. Georg-August-University, Göttingen (Germany).

31 Sarıby M.K., Do ruer G., Ergün Y., Karaca F. \& Ate C.T. 2008. Estrous induction in lactating hair goats outside the breeding season by flourogestone acetate containing vaginal sponges; the effect of GnRH and hCG applications on fertility. Eurasian Journal of Veterinary Science. 24(1): 21-27.

32 Simoes J. 2015. Recent advances on synchronization of ovulation in goats, out of season, for a more sustainable production. Asian Pacific Journal of Reproduction. 4(2): 157-165.

33 Uslu B.A. \& Gülyüz F. 2009. The effects of GnRH injection after intravaginal sponge, CIDR-G and ear implant application in coloured Mohair goats during early anoestrus season. Kafkas Üniversitesi Veteriner Fakültesi Dergisi. 15(3): 385-390.

34 Zarkawi M., Al-Merestani M.R. \& Wardeh M.F. 1999. Induction of synchronized oestrous in indigenous Damascus goats outside the breeding season. Small Ruminant Research. 33(2): 193-197. 